from shallow criticisms and vindicates his legitimate claims to pre-eminence at the bar of both the scholarly judgement and public opinion. A lengthy bibliography at the end of the book adds value to the book.

$N$ Hariharan

Madurai

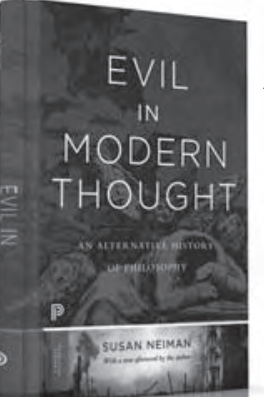

\section{Evil In Modern Thought: An Alternative History of Philosophy}

Susan Neiman

Princeton University Press, 4I William Street, Princeton, New Jersey 08540. USA. www.press.princeton.edu. 2015. xxii +382 pp. PB. $\$ 24.95$. ISBN 9780691168500 .

Jannah Arendt wrote about evil being so 1 banal that one does not recognise it when it is encountered in its esse (See Hannah Arendt, Eichmann in Jerusalem: A Report on the Banality of Evil (New York: Penguin, 1963). Arendt is central to any study of evil today and in her Afterword in this revised edition of her book originally published in 2002, Neiman re-evaluates Arendt. We will have the opportunity to speak of Arendt at the end of this review.

Jean Baudrillard sees evil as an intractable virus which has infected the cosmos:

In a society which seeks-by prophylactic measures, by annihilating its own natural referents, by whitewashing violence, by exterminating all germs and all of the accursed share, by performing cosmetic surgery on the negative-to concern itself solely with quantified management and with the discourse of the Good, in a society where it is no longer possible to speak Evil, Evil has metamorphosed into all the viral and terroristic forms that obsess us (Jean Baudrillard, The Transparency of Evil: Essays on Extreme Phenomena, trans. James Benedict (London: Verso, 2002), 8I).

Susan Neiman's book makes it possible once again to speak of evil explicitly; and thus seek ways to annihilate it. Her act of including the word 'evil' in the title of the book is the beginning of her cultural work as a philosopher who continues and responds seriously to the works of both Arendt and Baudrillard. Naming anything, and in this case, evil as it is, demands existential honesty in an atmosphere which does not want to discuss this ancient problem of evil which the Russian philosopher Nikolai Berdyaev felt was unsolvable. Neiman's book's praxis lies in its very existence: if we neglect the study of evil, genocides and terrorism will continue. Neiman, unlike most career philosophers, discusses terrorism in detail near the end of her book. The book under review has established the urgency of studying evil if one wants to truly comprehend what the philosopher-turned-novelist, Iris Murdoch had called the 'Sovereignty of the Good' (See Iris Murdoch, The Sovereignty of Good (London: Routledge, 1967)), which is the telos of all history, including Neiman's own reading of the history of philosophy as we find here. Neiman does not write on evil to exalt in it but to show how the sovereign nature of the good has been repeatedly apparently displaced by the existence of evil. Evil is no privatio boni or simulation vide Jean Baudrillard; it is very much a happening phenomenon. This reviewer has discussed about evil in Subhasis Chattopadhyay, 'Prolegomenon to the Study of Evil', Prabuddha Bharata, II8/4 (April 2013), 278-8I, 293.

Neiman has done successfully what no other contemporary philosopher has the temerity to do: she has shown how the history of philosophy demands new (mis)readings qua responses since evil is inherent in the esse of the idea of the being in the here and the now. Except Arendt and Baudrillard and to some extent Giorgio Agamben, contemporary philosophers have been silent on the problem of evil. Neiman says:

The picture of modern philosophy as centered in epistemology and driven by the desire to ground our representations is so tenacious that some philosophers are prepared to bite the bullet and declare the effort simply wasted. Rorty, for example, finds it easier to reject modern philosophy altogether than to reject the standard accounts of its history. His narrative is more polemical than most, but it's a polemical version of the story told in most philosophy departments in the second half of the twentieth century. ... What began as metaphysics - the description of 
the basic structure of reality-ended as epistemology: the attempt to ground the foundations of our knowledge (5-6).

Empirical research bears out the truth of her important thesis that the larger thematic study of the problem of evil took a backseat in professional discourses of philosophy during the last century and even in this century professional philosophers shy away from discussing the problem of evil since contemporary philosophy has engaged itself with 'timeless matters' like 'Goodness, truth, and beauty' (xvii). Yet 'Every time we make the judgment this ought not to have happened, we are stepping onto a path that leads straight to the problem of evil.... For it involves questions more natural, urgent, and pervasive than the skeptical epistemological quandaries said to drive modern philosophy' (5). Neiman is bold enough to attack Richard Rorty; a fact that will ensure that she remains a prophetic and therefore a marginalised voice within mainstream philosophy. Martha Nussbaum, in her magnum opus The Fragility of Goodness, for instance, keeps defining what Aristotle thought about the good life (See Martha C Nussbaum, The Fragility of Goodness (London: Cambridge University, 200I)). She, like Neiman, is a Jew; but she simply cannot face the spectre of Hitler. Yet she is venerated globally as the philosopher of Cosmopolitanism. How does reviving Cosmopolitanism from the detritus of the philosophy of the Cynics help one prevent the recurrence of the rise of another Hitler escapes this reviewer. Nussbaum nowhere attacks Rorty or A J Ayer-if she did so, she would not have been known universally as a humanist. Neiman errs on the side of being a rigorous scholar and pays for her rigour by remaining relatively yet undeservedly unknown.

In this book Neiman shows us how the Hitler event should have been tackled by professional philosophers and what exactly needs to be done to prevent mass genocides of the nature committed by the Nazis. Neiman studies the Lisbon earthquake and discusses Leibnitz and then correctly points out the epistemic retreat enacted by contemporary thinkers - this statement too has ensured that she remains an academic pariah. She is the only voice writing today asking the right questions: what happened to philosophising which dealt with the hard questions of life?
Why is it that some of the best minds of this and the last centuries avoid the issue of Hitler? Why do philosophy courses stress the abstract over the practical lived experience of the individual in the here and the now? Evil, that is 'absolute wrongdoing that leaves no room for account or expiation' (3), apparently defies all analyses. Thus, the reality and the inexplicability of evil forces an otherwise rigorous Alvin Plantinga to lose himself in the jugglery of logic while justifying the truth of evil and a benign God. Neiman's concern in this book is not God per se but rather the reality and inevitability of evil in all its forms and particularly, for example, why David Hume needs to be reread to understand evil-Neiman reads Immanuel Kant and then through him judges Hume and how the latter had effected the current course of philosophy and emasculated the academic domain or the study of philosophy. The section 'The Impotence of Reason: David Hume' in the second chapter is a tour de force in itself that should be made compulsory reading in all philosophy syllabi. This reviewer has scoured the internet and called up professional philosophers asking them whether they have read Neiman's contentions regarding Hume vis-à-vis Immanuel Kant elsewhere. None has. This chapter is sufficient reason for us to consider Neiman as one of the greatest philosophers alive.

Philosophers are notoriously bad stylists, but Neiman's style is cosy and jargon-free:

The question could be raised during a conversational lull in a good salon: would you live your life over, if given the chance? Eighteenthcentury thinkers took a rest from more serious business by discussing it. Few of them were entirely clear about the form of the question. Were they seeking an empirical survey, or a normative claim? Were they asking whether people in general, and any one of us in particular, would in fact repeat their lives over-or whether it would, on balance, be reasonable to do so? (206).

This is how Neiman begins writing on $\mathrm{Ni}$ etzsche in the section 'Eternal Choices: Nietzsche on Redemption' in the third chapter. Anyone familiar with Nietzsche will know from the title that Neiman is going to scrutinise Nietzsche in a way he has not been evaluated before: one should read this section for the scope of Neiman's own 
readings in philosophy and ancient Greek drama and for her power to connect philosophers as disparate as Voltaire and Hegel with Nietzsche keeping in mind her stated aim in this book. She never forgets to point out how all major Continental philosophers were writing willy-nilly on the problem of evil. She establishes that contemporary philosophers have got their priorities at least partially wrong: philosophy is in fact a coming to terms with the reality of evil. This reviewer recommends this section for another reason: stylistically it is one of the most lucid and witty treatments of Nietzsche that can be found in any history of philosophy. Neiman is aware that what she has written will not be accepted by her peers: hence she appends to the title 'An Alternative Philosophy of History'. But this is the history of philosophy which should be taught to neophytes and not the drab stuff which is the lot allotted as compulsory reading to philosophy majors.

Neiman is one of the few philosophers living today who can write about the reality of the Jewish cabal or 'lobby', and draw the ire of other Jewish philosophers:

Let me take an anti-Semitic bull by its horns and address the most common suspicion. There is indeed a Jewish lobby, more accurately known as AIPAC, which seeks to support right-wing Israeli governments who deflect responsibility for their own policies by emphasizing the ways in which Jews have been victims, particularly at the hands of the Nazis. But it is not responsible for the movement of popular consciousness from Hiroshima to Auschwitz. For decades following the war, survivors of Auschwitz were viewed with shame and even disgust; the newly founded Jewish state wanted heroes, not victims (345).

Neiman is frankly Jewish; she is ready to critique her Jewish peers and this is a kind of transparency not to be found even in Jacques Derrida, Michel Foucault, or Emmanuel Lévinas. All of them were Jews reacting to their understanding of the Torah and the Fall of Jerusalem, which is repeated in the Holocaust in a Nietzschean transvaluation of values and in the case of Derrida and Foucault; their own excommunications by orthodox Jews. Neiman's self-critique as a Jewish philosopher is refreshing. Her book The Unity of
Reason: Rereading Kant (See Susan Neiman, The Unity of Reason: Rereading Kant (New York: Oxford University, 1997)) had established her as a moral philosopher and this book secures her place as the only philosopher writing now worth reading, both for the truth about the history of philosophy as well as the real and not an alternative history of philosophy, as has been mentioned above.

Neiman contrasts Martin Heidegger with Theodor Adorno's conception and expectations of death (309). Her analysis of Heidegger is perfect within the context of this book. But she misses the point that it was Heidegger's Being and Time (1927) which triggered the retreat of philosophy into epistemology and to be precise, to become the study of language and other abstractions. Heidegger's complicity with the Nazis is well documented.

In this edition of the book we have Neiman revisiting Otto Adolf Eichmann. She takes into account recent historical research and partly modifies Eichmann's evaluation by Hannah Arendt. Neiman sees through Eichmann's pose as a humdrum bureaucrat and through now available documents from Argentina where Eichmann hid himself, she sees Eichmann as the true butcher that he was; a man well aware of Kantian categorical imperatives but bent on not applying these moral imperatives to his own butchery of the Jews. He boasted in Argentina of wanting to exterminate every Jew on earth. During his trial in Jerusalem, Eichmann as it now emerges, pretended to be just another regular person doing his job under orders from his bosses. Eichmann through this tactic of being banal wanted to live on and escape punishment-evil never wants to effect its own erasure from the world as it is.

One last point needs to be mentioned about Neiman's thorough research of evil-she asks the question whether the bombing of Hiroshima was necessary? Chances are that the Americans knew that destroying Hiroshima was not needed to win the war. It takes courage to revisit the evil that happened in Japan during the Second World War and accept that this evil was unleashed by those who were purportedly good.

Subhasis Chattopadhyay Assistant Professor of English, Ramananda College, Bishnupur 